\title{
DETERMINANTS OF INTERNAL TAX COMPLIANCE COSTS: EVIDENCE FROM SOUTH AFRICA
}

\author{
Sharon Smulders* \\ University of Pretoria
}

\author{
Riel Franzsen+ \\ University of Pretoria
}

Received: October 2015

\author{
Madeleine Stiglingh\# \\ University of Pretoria
}

\author{
Lizelle Fletcher\#\# \\ University of Pretoria
}

Accepted: May 2016

\begin{abstract}
Being tax compliant generates costs and these costs affect small business tax compliance behaviour and contribution. This study uses multiple regression analyses to investigate the key drivers of small business's internal tax compliance costs (hours spent internally on tax compliance activities). This will assist Revenue Services in understanding what factors (determinants) could increase a small business's internal tax compliance costs and might assist in managing tax compliance behaviour and contribution. The results expose the significant determinants per tax type, enabling a comparison to be made across the different tax types. Overall, turnover is the variable that had the most significant influence on internal tax compliance costs (time) (as opposed to the number of employees, which had a significant effect only on the internal time spent on employees' tax). The analysis confirmed that there is a higher proportional burden for smaller businesses in respect of internal income tax and employees' compliance activities.
\end{abstract}

Keywords

Internal tax compliance costs, regression analysis, small business, tax compliance burden, tax compliance costs

\footnotetext{
*Prof SA Smulders is an associate professor in the Department of Taxation, University of Pretoria, South Africa [sasmulders@gmail.com].

\#Prof M Stiglingh is a professor in the Department of Taxation, University of Pretoria, South Africa.

+Prof R Franzsen is a director at the African Tax Institute, University of Pretoria, South Africa.

\#\#Dr L Fletcher is a senior lecturer in the Department of Statistics, University of Pretoria, South Africa.
} 


\section{INTRODUCTION}

Globally, the small business sector is recognised as vital for economic growth and job creation (Anyadike-Danes, Bjuggren, Gottschalk, Hölzl, Johansson, Maliranta \& Myrann, 2015:822; Killian, Karlinsky, Payne \& Arendse, 2007:16; 0ECD, 2009:22; SBP, 2013:4). Despite its critical role in the economy, this sector faces serious challenges, one of which is the regulatory and legislative burden imposed in the form of tax legislation (Evans, Hansford, Hasseldine, Lignier, Smulders \& Vaillancourt, 2014:454; OECD, 2010:5; SBP, 2013:22). One of the elements of the tax burden is the tax compliance burden - the amount of time and money (compliance costs) spent in order to comply with tax laws (Charron, Chow \& Halbesma, 2008:iv; Coolidge, Ilic \& Kisunko, 2009:4; Guyton, 0'Hare, Stavrianos, \& Toder, 2003:676).

Compliance with tax legislation thus generates costs and one might ask why scholars, businesses or revenue authorities should be interested in computing and evaluating these tax compliance costs. One of the reasons is that tax compliance costs disincentivise business start-ups, reduce business productivity and diminish business resources, without raising income for the government, resulting in a waste of economic resources and ultimately lowering the living standards of a country's citizens (Charron et al., 2008:iv; Eichfelder \& Schorn, 2009:2; 0ECD, 2010:7). According to Klun and Blazic (2005:419), these costs also affect the economic behaviour of both individuals and businesses and seem to be connected to the level of compliance in that they could result in an increase in tax evasion (Erard \& Ho, 2003; Sapiei \& Kasipillai, 2013).

Conversely, a reduction in tax compliance costs could facilitate and enhance the productivity and international competitiveness of small businesses, which in turn would allow these businesses to apply more resources to essential business activities and increase their employment capacity and wage rates (Inland Revenue (New Zealand), 2007:1; Vaillancourt, cited in Charron et al., 2008:iii).

It is for these reasons that governments around the world have been taking tax compliance cost research seriously (Investment Climate Advisory Services, 2011:1; Lignier, Evans \& Tran-Nam, 2014). A review of tax compliance costs can therefore no longer merely be the focus of an academic study or an afterthought in the formulation of tax policy, but should be given serious attention by governments (Charron et al., 2008:v).

Three broad components have emerged as the indisputable core elements of tax compliance costs (Evans, 2006:3; Turner, Smith, \& Gurd, 1998:96; Tran-Nam, Evans, Walpole, \& Ritchie, 2000:229; OECD, 2009:16), namely

- taxpayers' and unpaid helpers' time (internal tax compliance costs);

- tax practitioners' fees (external tax compliance costs); and

- incidental expenses.

The first component (internal tax compliance costs) is the focus of this study.

Internal tax compliance costs include the cost of labour or time devoted to tax activities, for example, the time taken by a business person (an owner), the person's employee (a manager/internal bookkeeper/accountant/other employee handling taxes) or an unpaid friend or relative to learn and understand the tax law and the obligations the law imposes, or the time taken to obtain documents and data to complete a tax return (Blumenthal \& Slemrod, 1995:39; Evans, 2008:451; Klun \& Blazic, 2005:418). 
Smulders, Stiglingh, Franzsen and Fletcher (2012) found, in one of the largest studies of its kind conducted on the tax compliance costs incurred by small businesses in South Africa, that internal tax compliance costs increase as the size of the business - based on turnover - increases. The purpose of this study is to explore what factors, other than turnover, could have an effect on a small business's internal tax compliance costs.

The remainder of the study is organised as follows: section 2 explains the research methodology used, section 3 sets out the results and section 4 concludes the study.

\section{RESEARCH METHODOLOGY}

The data for this study emanated from a survey performed by Smulders et al. (2012), where the researchers collected data from small businesses registered with the South African Revenue Service with a turnover of less than R14 million. The questionnaire was sent out to 88057 small business taxpayers with a response rate of $6.7 \%$ (5865 respondents). The design of the electronic questionnaire was based on international best practice.

This study is positioned within the positivist paradigm and follows a quantitative approach. Inferential statistics, specifically regression analysis, is used in the data analysis process.

\subsection{Regression analysis}

Field (2009:198) describes a regression analysis as a statistical tool used to examine the relationship between variables (anything that can be measured) by ascertaining the casual effect of one variable upon another single variable (simple regression) or upon more than one variable (multiple regression). A multiple regression analysis was considered an appropriate tool for the analysis of internal tax compliance costs because analyses of this nature are typically used to show the applied value of research findings (Murphy, Hashim \& 0'Connor, 2007:3).

In order to determine the variables (called the independent variables or explanatory variables predictors) that have an effect on the internal tax compliance costs (called the dependent variables), a review of the literature was performed in order to develop hypotheses about the independent variables that could possibly have an effect on internal tax compliance costs, as suggested by Eichfelder and Schorn (2008:5). Hypotheses were developed only for independent variables for which data was available.

The assumed influence of these independent variables on tax compliance costs were investigated using a multiple regression analysis (as suggested by Field, 2009:198 and Murphy, Hashim \& 0 'Connor, 2007:3). The General Linear Model (GLM) procedure in Statistical Package for the Social Sciences (SPSS) was adopted because it readily accommodates both categorical and continuous predictors (Downs \& Stetson, 2011; Smith \&Hume, 2005).

Following the approach used by Hasseldine and Hansford (2002:381), once the initial regression analysis had been performed and the results analysed, the analyses were re-run but this time including only those independent variables that were found to be significant in the first regression analysis. This was done to determine whether the model specifications were robust or not. The results from all these analyses are discussed after the hypotheses and regression models used have been explained. 


\subsection{Hypotheses}

A hypothesis is a prediction about the state of the world (Field, 2009:787). A regression analysis tests hypotheses - by determining which predictor variables (independent variables) contribute substantially to the regression model's ability to predict the outcome (dependent variable), or explain the variability in the dependent variable. Predictor variables should be included in a regression analysis only if there are sound theoretical reasons for expecting them to influence the dependent variable (Field, 2009:225).

The literature revealed that various studies used regression analyses to determine the influence of independent variables on tax compliance costs, but they did so in general and not per tax type (DeLuca, Greenland, Guyton, Hennessey, \& Kindlon, 2005; Eichfelder \& Schorn, 2008; Reekmans \& Simoens, 2010;). However, Hasseldine and Hansford (2002) considered variables that influence only Value Added Tax (VAT) tax compliance costs and Blaufus, Eichfelder and Hundsdoerfer (2011) considered variables that influence only income tax compliance costs. This study will consider what the significant determinants were for each tax: VAT, income tax, employees' tax (commonly referred to as Pay-As-You-Earn (PAYE)), capital gains tax (CGT), turnover tax, customs and excise duties. This will enable a comparison to be done to understand whether or not these determinants are the same across the different taxes.

The independent variables, namely, the province (Eichfelder \& Schorn, 2008); gender and marital status (Blaufus et al., 2011); psychological factors (Eichfelder \& Schorn, 2008; Hasseldine \& Hansford, 2002); administrative strategy ( $($ ichfelder \& Schorn, 2008, 2009); and use of electronic data interchange ( $\varepsilon$ ichfelder \& Schorn, 2009; Yilmaz \& Coolidge, 2013) were identified as factors affecting (internal) tax compliance cost, but no survey data was available to include these factors in this study and is an area for future research. The following hypotheses were derived for the other independent variables that were found to impact internal tax compliance costs and for which this study does have data available:

- Business size - As the size of the business increases, the absolute internal tax compliance costs also increase (Coolidge et al., 2009:3). Three measures of business size can be used turnover, number of employees and gross asset value (South Africa, 1996). Only turnover and number of employees were available from the data. To determine which one of these variables has a stronger impact on internal tax compliance hours/costs, both variables were included in the analysis. Hence, the hypothesis that internal tax compliance cost will increase as the turnover and number of employees in a small business increases.

- Sector - The sector in which a small business operates is not a significant determinant of internal tax compliance costs (Reekmans \& Simoens, 2010:36). However, Hasseldine and Hansford (2002:382) found that some sectors (such as manufacturing, services and dealing in goods sectors) incurred lower VAT compliance costs than other sectors; Eichfelder and Schorn (2008:14) also found that the services sector had higher tax compliance costs (including the time burden) than the building sector. The results of the Smulders et al. (2012) study found that the transport, postal and warehousing sector followed by the public administration and safety sector spend the most time on internal tax compliance activities, but reasons for this were not immediately evident. There was no consistency in the local and international literature regarding the significance of sector on internal tax compliance costs. In addition, no other research in South Africa has indicated that the sector has a significant effect on tax compliance costs. Hence, the hypothesis that the sector in which a small business operates is not a significant determinant of internal tax compliance costs was retained for the purposes of this study. 
- Legal form - Sole proprietors spend more time on internal tax activities than Close Corporations (CC) and companies that tend to outsource their tax compliance activities (Blaufus et al., 2011:10).

- Business age - Younger businesses incur lower internal tax compliance costs than more established businesses. This is due to a lower degree of tax complexity compared to that of a more established businesses (Eichfelder \& Schorn, 2008:11).

- Use of small business tax concessions - Using the small business tax concessions increases the internal tax compliance costs incurred by small businesses, because the complexity of these concessions result in more time being spent in order to understand and apply these concessions (Freedman, 2006:59, 2009:156; Pope, 2008:33).

- Level of education - Businesses that have owners/employees who have at least a university degree or higher incur greater internal costs and spend more time on tax compliance than those who have no university degree, as they tend to be more interested in compliance work and tax planning (Blaufus et al., 2011:11).

- Accounting knowledge - Internal tax compliance costs decrease the higher the level of accounting knowledge that the owners/employees have as less time needs to be spent on understanding the tax implications of most accounting transactions (Blaufus et al., 2011:11).

- Use of external service provider - Using the services of an external service provider decreases the internal tax compliance costs (time) compared to a business that does not use these services (Coolidge et al., 2009:26).

- Accounting system used - A business using a computerised accounting system for tax compliance, as opposed to a manual system, should have higher internal tax compliance costs. This is due to high annual licence fees and training costs required in order to operate these systems correctly (Hasseldine \& Hansford, 2002:382).

These hypotheses were tested using a multiple regression model, as explained in the next section.

\subsection{Regression model}

The above hypotheses and the statistical significance of their predicted effect were assessed using the following model for internal tax compliance costs:

$$
\begin{gathered}
Y_{T C C}=b_{0}+b_{1} X_{\text {Employees }}+b_{2} X_{\text {Sector }}+b_{3} X_{\text {Legalform }}+b_{4} X_{\text {Age }}+b_{5} X_{\text {Turnover }} \\
+b_{6} X_{\text {Concessions }}+b_{7} X_{\text {Education }}+b_{8} X_{\text {AccKnowledge }} \\
+b_{9} X_{\text {Outsourcing }}+b_{10} X_{\text {AccSystems }}+\varepsilon
\end{gathered}
$$

The model in essence calculates what the effect of each independent variable (number of employees, sector, legal form, age, turnover, use of small business concessions, level of education, accounting knowledge, use of an external service provider and type of accounting system used) is on the internal tax compliance costs. The internal hours spent on tax compliance activities were used to represent the internal tax compliance costs. Reference categories for the categorical variables were chosen based on the categories that the majority of the respondents to the survey had chosen. In most instances, the reference categories were also in line with the literature mentioned above, in the hypotheses. A check for multicollinearity was performed and the diagnostic test revealed that the assumption of independence was not violated. 


\subsection{Regression procedure}

A regression analysis was run per tax type using the hypotheses (Model 1). The determinants that were considered to have a significant impact on the internal tax compliance costs were identified. The results were evaluated (section 3.1 - 3.7) and the regression analysis was then re-run (Model 2 - a parsimonious model) using only those significant determinants identified from Model 1 . Any differences between Model 1 and Model 2 were then evaluated (section 3.8).

\section{REGRESSION ANALYSES RESULTS}

The results are discussed in the following order: VAT, income tax, PAYE, CGT, turnover tax, customs duty and excise duties. It is acknowledged that for all of the taxes concerned, other than perhaps for customs duty and excise duties, the coefficient of determination $\left(R^{2}\right)$ is very low (ranging from $0.062-0.150$ ), indicating there are factors other than those considered in each of these models that have an effect on the number of hours spent on internal tax compliance activities in respect of each tax. Additional research would need to be performed in order to determine what exactly these factors are, but this is beyond the scope of this study, hence these factors are not considered further. Although the coefficient of determination is low, it is nevertheless considered valuable to report the findings of each model.

\subsection{VAT}

The multiple regression analysis performed on the internal hours spent on VAT reveals that the legal form, turnover, use of external service providers and the type of accounting system used had a significant effect on the internal tax compliance costs.

In respect of legal form, sole proprietors (Beta $=0.375$ ) were found to have spent significantly more time on internal tax compliance activities than CCs $(B e t a=0.000)$. Companies $(B e t a=0.302)$ also spent more time than CCs but still spent less time on compliance than sole proprietors. These findings are in line with the hypothesis that sole proprietors perform most of these functions themselves, whereas CCs and companies tend to outsource these functions (Blaufus et al., 2011:10). VAT is a fairly routine task and this could also explain to some extent why the sole proprietors would perform this function in-house rather than obtain the services of an external service provider.

The model further shows that the number of hours spent on VAT compliance increase as the size (based on turnover) of the business increases (Beta ranging from - 0.411 for the smallest to 0.319 for the largest), which is in line with the hypothesis. This is understandable because entities with taxable supplies (similar to turnover) of Rl million or less need not register for VAT. Another reason could be that generally the number of transactions would increase as the size of the business increases, resulting in more VAT transactions and thus more time spent on compliance.

The use of an external service provider (Beta $=0.257$ ) to assist with VAT functions increases the number of hours spent on internal VAT compliance, according to the model. This is in contrast with the expectation of the hypothesis that the hours would decrease. Coolidge et al. (2009:26) provide a possible explanation for this: they argue that when small businesses partially outsource, this leads to a duplication of work and effort, as the external service provider has to check what the small business has done, and where necessary must make the necessary corrections. Whether or not this is the case for the respondents in this study cannot be established from the data, as the 
questionnaire did not ask about which taxes outsourcing was required for. More research into the extent of outsourcing, and for which tax outsourcing is used, would need to be undertaken in order to reach a definitive conclusion on this matter.

Using a computerised accounting system increases the number of hours spent internally by small businesses on tax compliance activities (Beta $=-0.337$ ), which is in line with the hypothesis. As Hasseldine and Handsford (2002:382) explain, when businesses use a manual system, it is perhaps an indication that they do not place a high value on the time taken to perform these functions or that businesses using a computerised system require more training time in order to be able to use the system.

If Model 1 is compared to Model 2, it is evident that each of these variables continue to be statistically significant at conventional levels, although the time taken by private companies (Beta $=0.456$ ) is now higher than that of sole proprietors (Beta=0.203), contradicting the hypothesis. This finding indicates that perhaps these entities also tend to perform this routine function in-house. Trusts spent the least amount of time on this tax function (Beta=-0.472), generally because trusts are not used often for business purposes (Rhone, 2011:3).

\subsection{Income Tax}

The variables that were found to have a significant effect on the income tax internal tax compliance costs were legal form, turnover, level of education of the respondent and accounting knowledge of the respondent.

With regard to the legal form of the business, sole proprietors (Beta=0.441) spent significantly more time on tax compliance activities than CCs did. Companies (Beta $=0 .-0.041$ ) spent less time on these activities than CCs. Both these findings are in line with the hypothesis that sole proprietors perform most of these functions themselves, whereas CCs and companies would tend to outsource these functions, generally because their businesses are more sophisticated (Blaufus et al., 2011:10).

Although the results show that the number of hours needed to perform income tax compliance activities increases as the size (based on the turnover) of the business increases (in line with the hypothesis), these increases are not significant per turnover band (Model 1). This implies that the size of the business has very little effect on the number of hours a business has to spend on income $\operatorname{tax}-$ an indication of the burden faced by the smaller businesses. Model 2, however, reveals that businesses with a turnover of R3 million or more $(B e t a=0.157)$ tend to spend significantly more time on income tax compliance activities than businesses with a turnover of between Rl million and $R 3$ million ( $B e t a=0.000$ ). This could be because these businesses are involved in more complex transactions and do more tax planning.

The hypothesis that businesses employing persons with university qualifications (Education) (Beta $=0.311$ ) spend more time on internal tax compliance activities than businesses with fewer or lower qualifications (Beta $=-0.077$ ) is proved in respect of income tax in both Model 1 and Model 2. These individuals are probably more interested and educated in tax compliance activities and tax planning and thus tend to spend more time on these functions.

The hypothesis that internal tax compliance costs decrease the higher the level of accounting knowledge of the owner/employee was not confirmed by the results of the regression analysis: the higher the qualification of the owner/employee (Beta $=0.0 .086$ versus Beta $=-0.236)$ ), the more time was found to be spent internally on these activities. An exception to this finding is persons 
with basic bookkeeping knowledge (Beta $=-0.236$ ), who spent less time on income tax compliance activities than those with no accounting knowledge (Beta $=-0.055)$. This is probably because those with no accounting knowledge also have no or very little tax knowledge and thus require more time to come to grips with the tax legislation. Despite this, overall the results indicate that having more accounting knowledge increases the tax compliance time, possibly because these individuals are able to pick up more of the tax issues involved in the business, whereas those with less knowledge might not be aware that there are any possible tax issues. This might also be an indication of more tax planning taking place by individuals with better accounting knowledge.

If Model $l$ is compared to Model 2 , it is evident that each variable continues to be statistically significant at the conventional level, other than those already discussed above.

\subsection{PAYع}

The number of employees, turnover, accounting knowledge of the respondent and use of an external service provider were found to have a significant effect on the PAYE internal tax compliance costs. The fact that number of employees is significant is to be expected, because PAYE is paid by a business (employer) in respect of each of its employees.

Although the models indicate that there is a significant effect $(p=.023)$ on the number of hours spent on PAYE activities as the number of employees increases, this effect is very small (Beta $=0.004$ ), indicating that as the number of employees increases by one, so will the internal hours spent on PAYE compliance activities increase by 0.004 hours. This implies that there are economies of scale as the number of employees increase. This result proves the hypothesis that the number of hours needed to perform PAYE compliance activities increases as the number of employees increase. However, it also demonstrates that this increase is not very large - again indicating a larger burden for the smaller businesses.

Model 1 indicates that the size of the business based on turnover is more significant than the number of employees $(p=.000$ versus $p=.023)$. A reason for this increase in the number of hours spent on PAYE could be the increase in complexity of calculating PAYE for the employees (such as offering fringe benefits) when the turnover of the business increases, because more senior employees would be required to operate a larger turnover business. Model 1 and Model 2 show the trend that the number of hours spent on PAYE increases as the turnover of the business increases, confirming the hypothesis (Beta ranging from -0.390 for the smallest to 0.307 for the largest).

The hypothesis that internal tax compliance costs should decrease the higher the level of accounting knowledge of the owner/employee is contradicted, because the higher the qualification of the owner/employee, the more time was found to be spent on these activities (Model 2 (Beta $=0 . .09$ compared to -0.225$)$ ). Once again, this might be because these individuals are able to pick up more of the tax issues involved in the business, whereas those with less knowledge might not be aware that there are any possible tax issues. These higher educated individuals are also more likely to do tax planning than those with a lower level of education.

It appears that businesses still spend a significant amount of internal time on PAYE, even though they make use of external service providers, contradicting the hypothesis. This is again an indication that using partial outsourcing is not ideal. More in-depth research would be needed to establish exactly what outsourcing services were obtained before relying on this conclusion, although a regression analysis was run using the question relating to the use of external service providers for payroll functions and the results obtained remained the same. 
If Model 1 is compared to Model 2 , it is evident that the signs remain the same for each variable and all continue to be statistically significant at the conventional level, but Model 2 does clearly indicate the significance of turnover on the internal tax compliance costs for PAYE.

\subsection{CGT}

The variables that were found to have a significant effect on the CGT internal tax compliance costs were the sector and age of the business. The fact that turnover (or number of employees) is not a factor is understandable, because CGT is not based on the size of the business but on the size and type of assets that the business has (and then sells). Although it is to be expected that larger businesses may have more assets (and thus pay more (GT), this would be the case only if a business actually sells such assets.

In terms of Model 1 , the finance sector spent the most time relative to the professional services sector on complying with CGT (Beta=0.564), followed by the construction sector ( Beta=0.190). The reason for the finance sector spending more time on this tax than any other sector was slightly puzzling, but when Model 2 was analysed it revealed that the finance sector is not the sector that spends the most time on CGT compliance (Beta $=-0.111$ ), but rather the construction sector that spends the most time on CGT compliance (Beta=0.134). The number of hours spent by the construction sector on CGT can be explained more easily, as businesses in this sector would generally have a lot of valuable equipment such as graders, earthmoving equipment and forklifts to assist with their building endeavours and thus would be expected to be spending more time calculating and paying this tax when replacing/selling those assets than any other sector. The administrative sector spends the least amount of time on CGT (Beta=-0.537). As the sector's name indicates, it would generally not have many capital assets that it would buy and sell and thus have to pay CGT on. These findings disprove the hypothesis that the sector does not have an influence on CGT compliance activities.

From an age perspective, it is the younger businesses that tend to spend more hours on CGT compliance (Beta $=0.451$ ), which contradicts the hypothesis. Reasons for this could be that the smaller businesses, due to their lack of experience or knowledge, take longer to understand and apply the CGT legislation (performing the CGT calculations) when they actually do sell their assets than the more experienced older businesses.

If Model 1 is compared to Model 2, it is evident that the signs remain the same for each variable and all continue to be statistically significant at the conventional level.

\subsection{Turnover tax}

Only the age and turnover of the business were found to be significant determinants of the number of hours spent on internal tax compliance for turnover tax.

The fact that turnover was a significant determinant is understandable, because in terms of the Income Tax Act (South Africa, 1962), this tax is applicable only to businesses with a qualifying turnover of Rl million or less. If only those businesses with a turnover of Rl million or less are analysed, it is evident that the smallest businesses (those with a turnover of less than R245 000) spent the least amount of time on this $\operatorname{tax}(B e t a=-0.388)$. The number of hours increases as the size of the business increases (confirming the hypothesis) - most likely due to an increase in the administrative and recordkeeping requirements. 
In respect of the age of the business, it was found that the younger businesses (Beta $=0.475$ ) spent more time on the turnover tax than the older ones (hypothesis contradicted). This again indicates that perhaps a lack of experience results in more time having to be spent on education and understanding the legislation before it can be applied.

If Model 1 is compared to Model 2 , it is evident that the signs remain the same for each variable and all continue to be statistically significant at the conventional level.

\subsection{Customs Duty}

The sector and accounting knowledge were considered significant determinants of the number of hours spent on internal tax compliance in respect of customs duty.

Although none of the sectors individually had a statistically significant effect on the hours spent on customs duty (Model 1$)$, the manufacturing sector had the smallest $p$-value $(p=.055)$. Model 2 , however, confirms that this sector is a significant determinant of customs duty internal tax compliance cost $(p=.009)$ - disproving the hypothesis. This result is plausible because this sector produces, exports and imports goods to be used in the manufacturing process. Thus, businesses in this sector ought to spend more time complying with this tax.

In terms of Model 1 , persons with basic bookkeeping knowledge (Beta $=-0.604)$ spent the least amount of time on this tax, probably because it is a specialised tax requiring the time of more skilled individuals in the business. However, the regression reveals that persons with no accounting knowledge spent the most time on this $\operatorname{tax}$ (Beta $=0.879$ ), seemingly refuting the above explanation. Reasons for this could be that accounting knowledge has little bearing on the time spent on customs duty. Compliance with this tax rather requires knowledge about procedures and forms (administrative knowledge). Otherwise, this finding reveals that these individuals spent more time on this tax (than perhaps a person with accounting knowledge would have) because they do not have accounting knowledge. Model 2 goes some way toward explaining this conundrum, as it indicates that the accounting knowledge of a person is no longer a significant determinant of customs duty. The hypothesis is thus neither proved nor disproved.

\subsection{Excise Duties/Levies}

Despite the coefficient of determination being the highest of all the models none of the determinants listed in the hypotheses had a significant effect on the dependent variable (hours) in respect of excise duties/levies. However, when the individual variables were considered, it was established that the manufacturing (Beta=1.266) and the finance sectors (Beta=1.546) spent the most time on the internal tax compliance activities relating to these duties and levies. As with customs duty, the number of hours spent by the manufacturing sector seems to be plausible, as it is the nature of this sector to import and export. The rationale for the finance sector is not so clear-cut and it would require further research to confirm why this is the case. As none of these determinants were significant overall, the Model 2 regression analysis was not run. No further consideration was given to these duties and levies, as they are not one of the major taxes incurred by small businesses. 


\subsection{Summary of determinants of the hours spent on internal tax compliance activities}

TABLE l provides a summary of the determinants (key drivers) that were found to have a significant effect (as per Model l) on the hours spent by small businesses on internal tax compliance activities. This will highlight what determinants could increase a small business's internal tax compliance costs and might assist in managing small business tax compliance behaviour and contribution.

TABLE 1: Summary of significant determinants of internal tax compliance costs - Model 1

\begin{tabular}{|c|c|c|c|c|c|c|c|}
\hline & VAT & $\begin{array}{l}\text { Income } \\
\text { tax }\end{array}$ & PAyE & CGT & $\begin{array}{l}\text { Turn- } \\
\text { over Tax }\end{array}$ & Customs & Excise \\
\hline \multicolumn{8}{|l|}{$\begin{array}{l}\text { Significant } \\
\text { determinants }\end{array}$} \\
\hline Number of employees & & & $x$ & & & & \\
\hline Sector & & & & $x$ & & $x$ & \\
\hline Legal form & $x$ & $x$ & & & & & \\
\hline Age & & & & $x$ & $x$ & & \\
\hline Turnover & $x$ & $x$ & $x$ & & $x$ & & \\
\hline \multicolumn{8}{|l|}{$\begin{array}{l}\text { Small business tax } \\
\text { concession }\end{array}$} \\
\hline $\begin{array}{l}\text { Level of education of } \\
\text { respondent }\end{array}$ & & $x$ & & & & & \\
\hline Accounting knowledge & & $x$ & $x$ & & & $X^{\star}$ & \\
\hline $\begin{array}{l}\text { Use of external service } \\
\text { provider }\end{array}$ & $x$ & & $x$ & & & & \\
\hline $\begin{array}{l}\text { Type of accounting } \\
\text { system used }\end{array}$ & $x$ & & & & & & \\
\hline$F$-value & 4.278 & 2.246 & 4.495 & 1.688 & 1.816 & 1.429 & 0.867 \\
\hline Significance & 0.000 & 0.000 & 0.000 & 0.014 & 0.008 & 0.045 & 0.017 \\
\hline Adjusted $\mathrm{R}^{2}$ & 0.048 & 0.019 & 0.048 & 0.033 & 0.043 & 0.051 & -0.023 \\
\hline
\end{tabular}

Source: Authors' analysis

* This was not regarded as a significant determinant in Model 2

As can be seen from TABLE 1 , not all the determinants have an effect on the time spent on each tax type. If the number of employees is considered, the fact that PAY $\varepsilon$ is the only tax for which this is a significant determinant is understandable, because this tax is calculated based on the remuneration paid by a business to each of its employees. It is also evident that the number of employees does not have as significant an effect on internal tax compliance activities as turnover does. The results indicate that the size of the business (represented by turnover) has a bearing on 
the tax compliance costs incurred by small businesses, and this finding strengthens this current study's argument for using turnover as an indicator of the size of a business.

When considering the sector of the business, although the hypothesis was that the sector in which a business operates should not have an influence on the tax compliance costs (hours), the findings of this study suggest that the hypothesis needs to be rejected in respect of CGT and customs duty, where the construction and manufacturing industries respectively have a significant effect on the number of hours spent on internal tax compliance activities.

The next determinant, the legal form of a business, had a significant influence on the number of hours spent on VAT and income tax compliance activities. The analysis reveals that sole proprietors spent the most time on these two taxes, which is in line with the hypothesis.

The age of the business was found to have a significant influence on the number of hours spent on CGT and turnover tax compliance activities. The hypothesis that younger businesses spend less time on internal tax compliance activities than older ones is rejected. The lack of experience or knowledge of the younger firms in respect of these two taxes could be one of the reasons for this finding, and it appears to be to their disadvantage.

Overall, the determinant that had a significant influence on the most taxes is turnover. All the taxes, excluding only CGT, customs and excise duties, are significantly affected by turnover. The hypothesis that as the turnover increases so do the hours spent on internal tax compliance activities is thus confirmed.

Using small business tax concessions was found not to have a significant impact on the internal hours spent on tax compliance activities, which meant that the hypothesis that the internal hours would increase if small business tax concessions are used could not be confirmed or rejected. The Smulders et al. (2012:212) findings support the hypothesis as it was found in that study that there is a perception that using small business tax concessions has resulted in a direct increase in small businesses' internal tax compliance costs. These findings should, however, not be viewed in isolation, as not all small business tax concessions were introduced to reduce internal tax compliance costs but rather to provide other (substantial) benefits in the form of immediate tax savings through a lower tax rate and accelerated allowances. For instance, it is reported in the 2015 Budget Review that the tax savings attributable to the small business corporation incentive amounted to R1467 billion (South Africa, 2015:134). It is also worth mentioning that despite the possible increase in internal tax compliance costs, it has been established that using the small business concessions reduces the external tax compliance costs incurred by small businesses.

The level of education of the taxpayer had a significant influence only on the time taken to comply with income tax, whereas the accounting knowledge of a taxpayer had a significant influence on income tax and PAYE compliance time. The higher the qualification (level of education) and the more accounting knowledge a taxpayer had, the more time was spent on tax compliance activities. These findings confirm the hypothesis in respect of the level of education (the higher the level of education, the more time is spent on tax compliance), but means that the hypothesis can be rejected in respect of accounting knowledge (the higher the level of accounting knowledge, the lower the time spent on internal tax compliance).

VAT and PAY are the taxes for which the use of external service providers have a most significant influence on the hours spent internally on tax compliance. The influence is not a positive one the hypothesis had to be rejected as the internal hours spent on these two taxes increased even when the services of an external provider were obtained. A possible explanation for this can be that the use of external service providers leads to a duplication of work and effort. More research 
into the extent of outsourcing would need to be undertaken in order to reach a definitive conclusion on this matter.

The type of accounting system used was a significant determinant only for VAT. The hypothesis in this instance was accepted, and it indicates that the use of a computerised system increases the in-house time needed to comply with VAT obligations.

\section{CONCLUSION}

This study uses multiple regression analyses to investigate the factors influencing small business internal tax compliance costs (hours spent on internal tax compliance activities). Not only did the regression analyses results provide information on the significant determinants per tax type but they also enabled a comparison to be made to understand whether or not these determinants are the same across the different tax types.

The statistically significant determinants of internal tax compliance costs included the following: number of employees (PAYE), sector (CGT and income tax), legal form (VAT and income tax), age of the business (CGT and turnover tax), turnover (VAT, income tax, PAYE and turnover tax), the level of education of the respondent (income tax), the accounting knowledge of the respondent (income tax and PAYE), the use of an external service provider (VAT and PAYE) and the type of accounting system used (VAT). In relation to these determinants, the following was established:

- Although Reekmans and Simoens (2010:36) established that the sector in which a small business operates is not a significant determinant of internal tax compliance costs, in the current study it was found that the internal hours spent on CGT and customs duty compliance were significant for the construction (CGT) and the manufacturing (customs duty) sectors.

- Using an external service provider did not appear to decrease the internal time spent by a business on tax compliance activities in respect of VAT and PAYE, as Coolidge et al. (2009:26) suggest it does.

- The higher the accounting knowledge of the taxpayer, the more time is spent on internal tax compliance activities in respect of income tax and PAYE; this is in contradiction to the findings of Blaufus et al. (2011:11).

- The more qualified the taxpayer, the more time is spent on income tax compliance activities. This finding supports the results of Blaufus et al. (2011:11).

- Sole proprietors spend more time on VAT and income tax compliance activities than any other form of entity does. This finding confirms the results obtained by Blaufus et al. (2011:10).

- In line with the findings by Hasseldine and Hansford (2002:382), the current study found that the use of a computerised accounting system increased the amount of time spent on internal VAT compliance activities.

- Businesses five years or younger spent more time internally on CGT and turnover tax compliance activities than those older than five years. This finding differs from those of Eichfelder and Schorn (2008:11).

Overall, turnover is the variable that had the most significant influence on internal time (as opposed to the number of employees, which has a significant effect only on the internal time spent on PAYE). This finding confirms previous research findings. The analysis also proved that there is a higher proportional burden for the smaller businesses in respect of internal income tax and PAYE compliance activities. 
These findings can inform Revenue Services of the factors that could affect small businesses tax compliance behaviour and tax contribution. This research will also ultimately assist small businesses, which are vital to a country's economy, to critically evaluate their internal tax compliance burden.

\section{Acknowledgement}

Sincere gratitude is extended to the South African Revenue Service for making this research possible and for giving permission in 2015 to publish this research. Special thanks also to the World Bank (Ms J Coolidge and Mr G Kisunko) for their valuable input and assistance with the research.

\section{LIST OF REFERENCES}

Anyadike-Danes, M., Bjuggren, C.M., Gottschalk, S., Hölzl, W., Johansson, D., Maliranta, M., \& Myrann, A. (2015). An International Cohort Comparison of Size Effects on Job Growth. Small Business Economics, 44(4), pp.821-844.

Blaufus, K., Eichfelder, S. \& Hundsdoerfer, J. (2011). The hidden burden of the income tax: compliance costs of German individuals - Discussion Paper. Available: http://dx.doi.org/10.2139/ssrn.1980211. (Accessed 16 May 2012).

Blumenthal, M. \& Slemrod, J. (1995). The Compliance Cost of Taxing Foreign-Source Income: Its Magnitude, Determinants, and Policy Implications. International Tax and Public Finance, 2(5), pp.3753.

Charron, L., Chow, G. \& Halbesma, J. (2008). The hidden tax burden - a business perspective on the cost of complying with taxes. Canadian Federation of Independent Business. Toronto: Royal Canadian Mint.

Coolidge, J., Ilic, D. \& Kisunko, G. (2009). Small Businesses in South Africa: who outsources tax compliance work and why? Policy Research Working Paper 4873, World Bank, Investment Climate Department, Regulatory Simplification Division. Available: doi:10.1596/1813-9450-4873. (Accessed 30 October 2010).

DeLuca, D., Greenland, A., Guyton, J., Hennessey, S. \& Kindlon, A. (2005). IBM Consulting Services. Measuring the Tax Compliance Burden of Small Businesses, Recent Research on Tax Administration and Compliance, Proceedings of the 2005 IRS Research Conference, 7-8 June 2005.

Downs, A. and Stetson, B. (2011). Economic Versus Non-Economic Factors: An Analysis of Corporate Tax Compliance. American Accounting Association Annual Meeting - Tax Concurrent Sessions. Available: http://ssrn.com/abstract=1905075 or http://dx.doi.org/10.2139/ssrn.1905075. (Accessed 22 September 2015).

Eichfelder, S. \& Schorn, M. (2008). Tax compliance costs and its determinants: Evidence from German businesses. Available: https://editorialexpress.com/cgi-bin/conference/download.cgi?db_ name=iipf64\&paper_id=358. (Accessed 10 June 2012).

Eichfelder, S. \& Schorn, M. (2009). Tax compliance costs: a business administration perspective. Diskussionsbeiträge des Fachbereichs Wirtschaftswissenschaft der Freien Universität Berlin, 2009(3). Available: http://hdl.net/10419/28090. (Accessed 11 November 2011). 
Erard, B. \& Ho, C.C. (2003). Explaining the U.S. income tax compliance continuum. efournal of Tax Research, 1(2), pp. 93-105.

Evans, C. (2006). Counting the costs of taxation: an exploration of recent developments. Sydney: University of New South Wales.

Evans, C. (2008). Taxation compliance and administrative costs: an overview. In Lang, M., Obermair, J., Schuch, J., Staringer, C. \& Weninger, P. (eds.) Tax compliance for companies in an enlarged European Community. Alphen aan den Rijn: Kluwer Law International. (pp. 447-468)

Evans, C.; Hansford, A.; Hasseldine, J.; Lignier, P.; Smulders, S. \& Vaillancourt, F. (2014). Small business and tax compliance costs: A cross-country study of managerial benefits and tax concessions. eJournal of Tax Research, 12(2), pp.453-482.

Field, A. (2009). Discovering statistics using SPSS, $3^{\text {rd }}$ edition. Dubai: Oriental Press.

Freedman, J. (2006). Why taxing the micro-business is not that simple:

a cautionary tale from the 'old world'. Journal of the Australasian Tax Teachers Association, 2(1), pp. 55-77. Available:

http://www.asb.unsw.edu.au/schools/taxationandbusinesslaw/atta/attajournal/Documents/5_Fre edman_JATTA_vol2_nol.pdf. (Accessed 10 November 2011).

Freedman, J. (2009). Reforming the business tax system: Does size matter? Fundamental issues in small business taxation. In: Evans, C \& Krever, R. (eds.) Australian Business tax reform in retrospect and prospect. Sydney: Thomson Reuters.

Guyton, J.L., O’Hare, J.F., Stavrianos, M.P. \& Toder, E.J. (2003). Estimating the compliance costs of the US individual income tax. National Tax Journal LVI-3 (September 2003), pp.673-688.

Hasseldine, J. \& Hansford, A. (2002). The compliance burden of VAT: further evidence from the UK. Australian Tax Forum, 17(4), pp.369-388.

Inland Revenue (New Zealand). (2007). Reducing tax compliance costs for small and medium-sized enterprises: A government discussion document. Available:

http://taxpolicy.ird.govt.nz/publications/2007-dd-compliance-costs-smes/overview. (Accessed 10 May 2012).

Investment Climate Advisory Services. (2011). Surveying businesses on tax compliance costs. Washington, DC: World Bank Group.

Killian, S., Karlinsky, S., Payne, G. \& Arendse, J. (2007). Mixed blessing of being designated a small business: A four country comparison. The ATA Journal of Legal Tax Research, 5(1), pp. 16-34. Available: http://aaapubs.org/doi/abs/10.2308/jltr.2007.5.1.16. (Accessed 10 November 2011).

Klun, M. \& Blazic, H. (2005). Tax compliance costs for companies in Slovenia and Croatia. Public Finance Analysis, 61(3), pp. 418-437.

Lignier, P.; Evans, C. \& Tran-Nam, B. (2014). Tangled Up in Tape: The Continuing Tax Compliance Plight of the Small and Medium Enterprise Business Sector. Australian Tax Forum: a journal of taxation policy, law and reform, 29(2), pp.1-38.

Murphy, J., Hashim, N.H. \& O'Connor, P. (2007). Take me back: validating the wayback machine. Journal of Computer-Mediated Communication, 13(1), pp. Article 4.

OECD. (2009). Taxation for SMEs - key issues and policy considerations. Paris: OECD Publication Service. 
OECD. (2010). Auditing small and medium sized enterprises 7. Importance of SMEs. Accra: Centre for Tax Policy and Administration.

Pope, J. (2008). Favourable small business taxation: to what extent is it justified from a tax policy perspective? Journal of Applied Law and Policy, 2(1), pp. 21-34.

Reekmans, C. \& Simoens, G. (2010). How high are the tax compliance costs for Belgian SMEs. Unpublished Masters Dissertation. Ghent: Ghent University.

Rhone, (2011). Foundation vs trust purposes, similarities \& differences of these estate planning vehicles. Available: http://www.rhoneservices.com/images/pdf/Foundation_vs_Trust.pdf.

(Accessed 2 August 2011).

Sapiei, N.S. \& Kasipillai, J. (2013). External tax professionals' views on compliance behaviour of corporation. American Journal of Economics, 3(2), pp.82-89.

SBP. (2013). Headline report of SBP's SME growth index - Growth and competitiveness for small business in South Africa, February 2013. Johannesburg: SBP.

Smith, A. and Hume, દ. C. (2005). Linking culture and ethics: A comparison of accountants' ethical belief systems in the individualism/collectivism and power distance contexts. Journal of Business Ethics, 62(3), pp.209-220.

Smulders, S. Stiglingh, M. Franzsen R. \& Fletcher, L. (2012). Tax compliance costs for the small business sector in South Africa- establishing a baseline. eJournal of Tax Research, 10(2), pp.184-226.

South Africa. (1962). Income Tax Act, No.58 of 1962. Available: http://www.acts.co.za/tax/index.htm. (Accessed 29 June 2011).

South Africa. (1996). National Small Enterprise Act, No. 102 of 1996. Available:

http://www.westerncape.gov.za/Text/2009/9/national_small_enterprise_act_102_of_1991.pdf. (Accessed 29 June 2011).

South Africa. Department of National Treasury. (2015). Budget Review. Available: http://www.treasury.gov.za/documents/nationalbudget/ 2015/. (Accessed 25 February 2015).

Tran-Nam, B., Evans, C., Walpole, M. \& Ritchie, K. (2000). Tax compliance costs: research methodology and empirical evidence from Australia. National Tax Journal, 53(2), pp.229-252.

Turner, J.L., Smith, M. \& Gurd, B. (1998). Auditing income tax self-assessment: the hidden cost of compliance. Journal of Managerial Auditing, 13(2), pp.95-100.

Yilmaz, F. \& Coolidge, J. (2013). Can E-Filing Reduce Tax Compliance Costs in Developing Countries? World Bank Policy Research Working Paper No. 6647. Available: http://ssrn.com/abstract=2337800. 